\title{
Transnational migration and the gendered right to the city in Buenos Aires
}

DOI:

10.1016/j.cities.2017.06.014

\section{Document Version}

Accepted author manuscript

Link to publication record in Manchester Research Explorer

\section{Citation for published version (APA):}

Bastia, T. (2018). Transnational migration and the gendered right to the city in Buenos Aires. Cities, 76, 18-22. https://doi.org/10.1016/j.cities.2017.06.014

\section{Published in:}

Cities

\section{Citing this paper}

Please note that where the full-text provided on Manchester Research Explorer is the Author Accepted Manuscript or Proof version this may differ from the final Published version. If citing, it is advised that you check and use the publisher's definitive version.

\section{General rights}

Copyright and moral rights for the publications made accessible in the Research Explorer are retained by the authors and/or other copyright owners and it is a condition of accessing publications that users recognise and abide by the legal requirements associated with these rights.

\section{Takedown policy}

If you believe that this document breaches copyright please refer to the University of Manchester's Takedown Procedures [http://man.ac.uk/04Y6Bo] or contact uml.scholarlycommunications@manchester.ac.uk providing relevant details, so we can investigate your claim.

\section{OPEN ACCESS}


Transnational migration and the gendered right to the city in Buenos Aires

Currently in press in Cities

Tanja Bastia

Global Development Institute

University of Manchester

$6^{\text {th }}$ June 2017

\title{
This is the AAM Author Accepted Manuscript. The final version is available online http://www.sciencedirect.com/science/article/pii/S0264275116301834
}

\section{Acknowledgements}

I would like to thank cities@ manchester for financing the pilot project on which this article is based. This project was carried out in collaboration with Jerónimo Montero-Bressán, who helped organise fieldwork and carry out the interviews. I am also grateful to all the participants and interviewees, without whom this project would not have been possible.

\begin{abstract}
Cities are important sites for the construction of social citizenship. However, they are also highly differentiated, both spatially and in terms of the social inequalities that pervade everyday urban life. Based on interviews conducted with grassroots and migrant organisations at the city level and in three informal settlements in Buenos Aires in 2013, this paper explores two dimensions of disadvantage: gender and migration status. Women and men who participate in grassroots and migrant organisations generally do so from a similar analysis of the problems they aim to address. However, they position themselves differently in relation to the idea of doing politics. While men generally embrace politics, women are much more likely to reject the suggestion that their work is political and prefer highlighting the assistentialist aspect of the organisations in which they are active. The paper explores some of the reasons behind these differences and asks whether this different conceptualisation of politics has implications for women's and men's claim to a 'just city'.
\end{abstract}

\section{Introduction}

For Lefebvre, the right to the city was premised on two foundations: the appropriation of urban space and participation in the decisions that have consequences for citadins, those inhabiting the city (Lefebvre 1996). However, the right to claim rights (Arendt 1988) itself, is not a given right. Not everyone feels that they have the right to make a claim on the rights they are entitled to. This ability to claim rights is fundamental for the construction of a just city. However, the process of defining who has the right to claim rights is usually done within the sphere of politics and requires further examination. 
Since the publication of Lefebvre's the Right to the City in 1968, many have adopted his utopian view of the city as the basis for critiquing the increasing neoliberalisation of cities and urban space across the world (Kipfer, Saberi, and Wieditz 2013; Brenner and Elden 2009). As we know, cities are highly gendered (Jarvis, Kantor, and Cloke 2009; Massey 1994; DeSena 2008) and women will also make up the majority of urban citizens in the near future (Chant and McIlwaine 2016). However, there has been relatively little work exploring the gendered dimension of Lefebvre's ideas.

Migration represents an additional aspect of differentiation in today's cities. Many cities are now hosts to an increasing number of migrants, a result of global inequalities, the increasing interconnected nature of our lives, cheaper transport and easier communication (Castles and Miller 2009). Lefebvre did not take these aspects of city life into consideration in his formulation of the right to the city, despite the fact that he argued for greater attention to be paid to difference (Buckley and Strauss 2016). There is therefore a need to review his ideas in light of the presence and importance of migrants in today's cities.

This paper addresses both an empirical and a conceptual gap in Lefebvre's work; that of cities becoming home to an increasing number of migrants as well as the lack of attention paid to gender in the city. Gender and migration are here understood as two fundamental aspects of social stratification that lead to unequal access to participation. To further explore how gender and migration influence participation and appropriation in today's cities, the paper draws on interviews with migrant and grassroots organisations in Buenos Aires, a city that has seen large scale mobilisations since the 2001 crisis and is also the regional attraction pole for migrants from neighbouring countries.

\section{The right to the city, gender and migration}

Since the publication of the Right to the City, many have seen the usefulness of adopting a Lefebvrian perspective on the urban (Buckley and Strauss 2016; Kipfer, Saberi, and Wieditz 2013; Brenner and Elden 2009; Madden 2012), particularly those who see in Lefebvre's writings the potential to challenge the encroachment of neoliberal values in every aspects of urban life (Purcell 2003; Peck and Tickell 2002). The fundamental point of Lefebvre's critique is that capitalism encroaches on urban space, which is turned into an asset and ceases to provide the opportunity for citizens to use that space, thereby diminishing its use value. People become alienated from urban space, unless they access it through their role as consumers (Miraftab 2007). For women, this has always been an issue given their lower earnings compared to men and the multiple demands on their time given their multiple responsibilities, from earning an income to caring roles. Lefebvre himself associated femininity with the non-urban (Buckley and Strauss 2016). For migrants, alienation from urban space is generally even more of an issue, particularly when they lack the correct documentation. Undocumentedness often leads to a more accentuated withdrawal from public space because of the migrants' fear of being harassed by the police, apprehended or deported.

For Lefebvre, two conditions need to be met if people were to have rights to the city and access to the 'oeuvre', the city as a work of art: participation in the decisions that have 
consequences for urban life and appropriation of urban space, or the valuing of its use value over exchange value (Kofman and Lebas 1996) even when those decisions might be taken elsewhere (Purcell 2003:578). However, as indicated above, citadins, or those people who live in the city, have always been differentiated according to class, gender, or race, among others. For them, "the right to inhabit the city - by different people and different groups - had always to be struggled for" (Mitchell 2003) (p.18). This is where politics becomes centralstage, given that it is in the political arena that decisions are made about who has the right to claim rights (Arendt 1998).

Lefebvre himself was quite vague in his text in terms of how the Right to the City could be operationalized. While giving a firm basis on the ideals that needed to be followed, such as appropriation and participation, he does not give concrete examples or directions on what changes are necessary in order to achieve the right to the city. Therefore, while proposing a useful and inspiring set of ambitions, Lefebvre left the specific inhabitants of the city out of his writing. When he does refer to citizens, he refers to elites, artists, the bourgeoisie and workers. This is not sufficient to account for the many different groups of people who live in the city and might be excluded from claiming their right to the city.

Cities have changed in significant ways since Lefebvre's Right to the city was published. First, the feminist movement that was already emerging in Europe when Lefebvre was writing his text provided the basis on which to critique the assumptions that underpinned society, such as the sexual division of labour and the limited and unequal incorporation of women in the labour market. It also highlighted the need for women to have greater control over their own bodies. Later critiques showed that some of these challenges arose out of the specific experience of white, middle-class women (Hill Collins 2009; hooks 1984), giving rise to a better acknowledgement of the diversity of feminist positions and women's movements worldwide (Lovenduski 2005).

Feminist critiques of urban research have shown that women and men have different experiences of the city (Chant and McIlwaine 2016). City institutions, including the labour market, are highly differentiated by gender. Women in cities have better access to paid work and gain greater spatial mobility as compared to their rural counterparts. They also become active in grassroots movements to challenge everyday injustices (Jarvis, Kantor, and Cloke 2009; Patel and Mitlin 2002; McIlwaine 2013). However, despite having improved our understanding of how women's lives differ in cities and in rural areas, the task of developing a feminist critique on the urban is yet to be conducted (Peake and Rieker 2013; Buckley and Strauss 2016; Chant and McIlwaine 2016). Despite decades of feminist critiques of urban theory that have shown the centrality of including gender in any understanding of the city, mainstream urban theory continues to fail to engage with feminist urban scholarship (Buckley and Strauss 2016). This includes exploring the gendered dimension of the Right to the City, particularly how women and men relate differently to participation and whether they have different perspectives about appropriation.

Second, the urban transition and the fact that a greater proportion of the population now lives in urban areas, give Lefebvre's writings greater weight. However, the same process also raises the question of how his writings and concepts might be relevant to the majority world, 
to the 'developing countries' that have greatly contributed to the acceleration of the urban transition. This is particularly the case given that developing countries, including its cities, are generally approached from a developmentalist perspective, that is, as in need of development, for which the answers are often assumed to be in or provided by higher-income countries (Robinson 2006; Peake 2015). Urban theory is still largely unable to overcome its Northern bias (Schindler 2014; Roy 2011). Postcolonial critiques of mainstream urban theory have argued against excessively negative views of cities in the Global South (Roy 2011) and for the need to 'provincialise' urban theories such as planetary urbanism (Derickson 2015) in order to start writing a theory from the South (Comaroff and Comaroff 2012; Simone 2010) so as to arrive at a theory that is truly global.

Third, the right to the city has now gone 'global' (Harvey 2008), not just in the sense of the global expansion of capitalism but also in terms of those who inhabit cities, with the increasing participation of migrants in urban labour markets (Sassen 1999; Purcell 2003). The presence of non-citizens raises further questions as to how the right to the city can be claimed given the temporality that is often imposed on the presence of migrants in cities and their differentiated relationship with the state. While migrants find work at both the highest and the lowest ends of the labour market, of particular concern are those in the most precarious jobs, working in the informal sector or the underground economy with weak or inexistent provision for the protection of their rights. In many countries in the Global South migrants often also end up living in informal settlements. This adds a further dimension to their exclusion and one that is compounded by the historic exclusion of those living in informal settlements from enjoying the supposed benefits of urban life in cities like Rio de Janeiro, Delhi or Lagos (Balbo 2007; Perlman 2010; Simone 2004; Davis 2007). The question then is whether migration provides an additional element of stratification in relation to how migrants and citizens relate to participation and appropriation.

This paper draws on 18 interviews with migrant and grassroots organisations in the city of Buenos Aires. The interviews were carried out by myself and an Argentinean research assistant with the aim of understanding how migrants organise and how their different forms of participation relate to the idea of a just city. We interviewed migrants and Argentineans, both women and men. Gender differences emerged as being quite fundamental in the ways in which our interviewees participated in everyday politics, both in terms of how others framed their participation but also how they themselves related to the politics of their participation. The sections that follow present these findings, after a brief section on the wider context of gender and migration in the city of Buenos Aires.

\section{Gender, migration and informality in Buenos Aires}

Argentina is well known for its historic European migration (Devoto 2003). However, regional migrations, particularly from Paraguay and Bolivia, have always been present alongside the better known European migration streams. These have received attention in the well-developed Argentinean scholarship on regional attention, but not in the international scholarship on Argentina. In Argentina regional migrations gained attention during the 1980s, 
when migration streams from neighbouring countries started shifting from the northern regions in Argentina towards Buenos Aires and were joined by more recent migrations from Chile and Peru. Coming into the centre of national political and economic life, these regional migrations became highly racialised in the media and national politics (Grimson 1999). While there has generally been a perception of an increase in the number of migrants from neighbouring countries over the last decades, it is important to point out that the share of people born in a neighbouring country and Peru has remained largely constant around 3 per cent of the total population, experiencing only a slight increase from 2.9 per cent to 3.1 per cent of the total population in the last 2001-2010 inter-censal period (INDEC 2012).

Less well documented is the feminisation of these regional migration streams. While there was a larger proportion of men who migrated to the northern Argentinean regions for agricultural work, the 1980s move towards Buenos Aires went hand in hand with a higher demand for workers in the service sectors. This led to a feminisation of these migration streams (Basok, Piper, and Simmons 2013).

Finally, during the last decade, while there has been a movement at the national level towards a more inclusive citizenship and a much greater recognition of migrants' rights, (Bastia and vom Hau 2014), at the city level citizenship has been more exclusionary. Migration in particular has been used by the city authorities as a reason to blame the increased housing informality and the expansion of informal settlements on migrants. This balance between a more supportive and open national government and a more coercive and discriminatory city government is set to change with the election of the conservative Governor of the City of Buenos Aires, Mauricio Macri, to the Presidency.

Given the increased visibility of migrants from neighbouring countries in the city of Buenos Aires and the city authorities using migrants as scapegoats for increasing levels of informality, we asked: how do migrants claim rights to the city? How do they organise? And, following on from the above about the need to include a gender perspective, are there significant differences in the ways in which women and men migrants engage in participation?

Our initial scoping study indicated that migrant organisations - identified as such by our interviewees - were active at the city level. These were largely organised around specific nationality groups: Peruvians, Bolivians, and Paraguayans. Many of these migrant organisations collaborated with city authorities as well as the governments of their respective countries of origin. Those leading these organisations claimed to represent specific nationality groups and were generally involved with formal political parties. Some aimed to set up their own political party in Argentina, while others mobilised the diaspora for supporting specific parties in their countries of origin. However, they generally lacked an understanding of the daily realities experienced by migrants from neighbouring countries. They also distanced themselves from highlighting the political dimension of controversial issues, such as the type of work that many migrants perform (e.g. garment workshops) or the type of housing they have access to (informal, with poor services). 
Within informal settlements, which is where many migrants from neighbouring countries live, migrants participated in grassroots organisations on the basis of their resident status, i.e. on the basis of inhabiting the city, albeit a specific type of neighbourhood, such as the informal settlement. These organisations were made up of migrants and Argentineans and were of mixed nationalities: Paraguayans, Bolivians and Peruvians participated together with Argentineans to respond to urgent needs of food and unemployment. They also embraced more strategic issues such as raising awareness of the housing crisis that the south of the city of Buenos Aires is facing. Unlike migrant organisations, grassroots organisations did not highlight the nationality of the people that participated in them, nor their migration status.

Within this broader context of nationality-based migrant organising at the city level and more class-based organising in informal settlements, there were further nuances in terms of who participated in which organisation and with what aims.

\section{'Doing politics' and gendered participation}

During fieldwork we were confronted with an issue of representation, in that women were not seen as 'doing politics'. At the beginning reaching interviewees proved challenging. We aimed to work in three informal settlements and snowballed from our initial list of contacts. However, almost half way into the project we realised that all the contacts that we were given were men. We therefore started asking more direct questions about women: which organisations do women participate in? At this point we were directed to soup kitchens.

Most of the women we talked to stressed the assistentialist ${ }^{\mathrm{i}}$ basis of their organisations. They highlighted the fact that they were providing a service for the benefit of the whole community, not along partisan lines. In addition, once we started talking to women we realised that women also did not see their work as political. Compared to previous research on feminising politics, which showed that women face specific barriers to entering formal politics (Lovenduski 2005), we found that women themselves chose not to see their work as political and therefore made little attempt to represent their organisations as doing political work (see also Naples 1991, 1992).

A good example to illustrate this point is our second interview, in which both partners participated: a man born in Paraguay and a woman of Paraguayan descent born in Argentina. He had been identified by our previous interviewee as a 'community leader'. In the interview she gave the floor to her partner and stayed in the background, intervening only when directly asked a question or adding some comments. He did most of the talking and was allowed to determine the narrative and the course of the interview. As the interview unfolded, it turned out that she had been the catalyst for his involvement in grassroots organisations. She told us that she had started engaging in grassroots organisations in the informal settlement when he was still just interested in finding a job after becoming unemployed during the crisis. However, he is the one who is generally identified as the leader of the grassroots organisation they both participate in.

The fact that women's participation in grassroots organisations was not seen as 'doing politics' was common and emerged in other interviews as well. In another interview, a young 
Paraguayan woman who ran a soup kitchen directly rated politics as 'machista'. Distinguishing community work and 'doing politics' she argued: "Yes, what goes at the community level, it is always going to be women who participate but politics is very machista" (Paraguayan woman in her 40s). When we probed her further, she drew a distinction between politics and civic participation:

"It is not political, it's community based [comunitario]. That which is related to the community is social, it's grassroots, I mean, it's for everyone, while the political, that which is related to political parties, is just for those who are part of the party" (Paraguayan woman in her 40s).

It became clear that this particular interviewee was articulating a wider concern that distinguished between 'politics' and 'the political' (Swyngedouw 2009). 'Politics' is here understood to relate to the sectarian interests of political parties and is often associated with corruption. 'The political' on the other hand refers to actions that lead to the expansion of democratic politics, to the Greek idea of polis, and is therefore for everyone. However, in this instance our interviewee understands the reach of 'politics' to be so wide to negate the possibility of 'the political', which is then subsumed with the communitarian.

As in other parts of the world, the women we interviewed generally regarded politics as 'unappealing' (Lovenduski 2005:13). Their stories echoed the experiences of women's community-based organising in the US, who also did not see their work as political (Naples 1991). However, while in the US example women aimed to challenge structural inequalities to improve their neighbourhood, our interviewees limited their actions to responding to basic needs. Naples' interviewees embraced their activism and referred to their work as "citizen activism" (p.485), which most of our interviewees did not.

The women we interviewed were generally depoliticised, not only by others but also in their own perceptions of their activities. Women were not seen as either 'doing politics' or engaging in 'the political'. They were not identified as leaders, even in cases when they held elected seats or led grassroots organisations. The organisations in which they participate were not seen as doing political work, even in cases where they challenged stereotypes or structural inequalities. Women themselves did not see their work as political and as making claims to the political. A Bolivian woman who had been running a soup kitchen since 1989 said: "I didn't understand anything about that, because my family had taught me to work and work ... I didn't know anything about politics" (Bolivian woman in her 40s), clearly distancing herself from anything involving politics or political parties.

When we asked our interviewees why only men were identified as leaders, they argued that this was because "women are not empowered" (Peruvian woman in her 40s). According to them this lack of empowerment resulted in women limiting themselves to participate in assistantialist organisations that serve the practical needs of the community, but without raising claims related to either the political or strategic gender interests (Molyneux 1985). 


\section{Spaces for change}

One might argue that women's participation in assistentialist organisations in activities that are an extension of their care roles reproduces unequal gender relations. A Peruvian woman leading a migrant women's organisation would certainly take this perspective given her work in breaking stereotypes (Peruvian woman in her 40s). However, there is also some evidence that these communal spaces, such as soup kitchens, also create opportunities that challenge patriarchal gender relations. For example, a Bolivian woman who ran a soup kitchen explained how initially her partner did not want her to spend so much time at the soup kitchen. However, she won that battle after insisting that the work was important to her (Bolivian woman in her 40s). She also talked about how they also use the soup kitchen as a shelter for women suffering domestic violence. She recalled how on one occasion they managed to get the man to leave the house, instead of the more common scenario where the woman and her children had to leave to go to a shelter or a relative. However, while clearly raising political issues, she also distances herself from the world of 'politics' (Swyngedouw 2009):

\footnotetext{
“And well, the soup kitchen, that's for sure, doesn't work politically. It doesn't matter which government is in power, because we came to the conclusion that ... this year we are celebrating 24 years of work here, and we have never allowed anyone to fly their political flag here [...] because I am not going to be doing politics with the children's empty bellies" (Bolivian woman in her 40s).
}

That is, she will not be using children's hunger for political gains.

However, some migrant organisations claiming to represent specific nationalities were, becoming very powerful through their connections with formal politics. Some of our interviewees were concerned that power was being concentrated in the hands of a few leaders (Bolivian man in his 30s). This problem also has a specific gendered dimension. First, because most of these migrant organisations are led by men. Second, because there is some evidence that some migrant organisations seem to be acting in parallel to the legal justice system. One migrant organisation representing Bolivians dealt with cases of domestic violence, among other issues, because, according to our interviewee, women prefer to go to them instead of going to the police. In his words:

"We're not going to get involved so much in their problems. Sometimes we can talk, for example, we can call [the man] and tell him: 'Brother, can we talk?' and they come because there is a lot of respect for us among our people and when we need them to, they come, they take us as if we were the authorities, which we are not, but sometimes they do" (leader of a migrant organisation in his $40 \mathrm{~s}$ ).

Clearly there are a number of problems with these developments. As stated above, all migrant organisations we interviewed were led by men, except for one that specifically represented migrant women. These migrant organisations are not trained for dealing with cases of domestic violence. They also have an inherent interest in keeping the trust of the migrants who come to them and therefore not referring cases of domestic violence to the Argentinean 
authorities. This statement also suggests that these migrant organisations are not aiming to empower migrant women and refer them of the public institutions that deal with domestic abuse, such as the police and the justice system. Instead, they try to deal with domestic abuse informally. This approach can overlook serious cases of abuse, leave perpetrators of violence free to keep abusing their partners and leave women in vulnerable and dangerous situations. Moreover, this approach can also lead to a parallel system of dealing with domestic violence for migrant women, who are then alienated from the mainstream one that is meant to deal with everyone, not just Argentineans.

For these women, therefore, while they might be represented by these organisations in terms of their nationality, their gendered interests are not being met. Their potential claims for a gendered right to the city, therefore, will find no support from migrant organisations. Grassroots organisations, similarly, tend to represent class-based interests of those living in informal settlements. While they might integrate a progressive feminist agenda, this is not the main focus they put forward in their claims. As seen above, in the case of the interview with the couple, women tend to defer to men in terms of public speaking and men tend to be identified with leadership positions. The organisations that seem to provide the greatest potential for pushing forward a gendered right to the city are the assistentialist organisations, which are led and run by women, but generally tend not to see their work as political. In line with other working-class women's organisations in Latin America, they also tend to reject a feminist rhetoric and see themselves more as service providers and working for the benefit of the whole community, particularly the most disadvantaged (Barrios de Chungara, Viezzer, and Ortiz 1979). Nevertheless, while doing so, they also raise the potential for creating new spaces where women can come together and make more progressive claims (Laurie 1999), as indicated above in the case of the soup kitchen turned domestic violence shelter.

\section{Conclusion}

Given that Lefebvre's Right to the City is used worldwide as a rallying cry by social movements to claim more inclusive and more just cities, it is imperative that we also broaden our understanding of these key ideas at the conceptual level. Participation is a fundamental principle of the Right to the City and, as argued in this paper, we cannot really understand participation without taking into account the political sphere where the right to claim rights is determined. The examples from Buenos Aires further illustrate how it is possible for migrants and non-migrants to participate together in grassroots organisations that aim to highlight the housing crisis in the southern part of the city of Buenos Aires. This coming together and organising on the basis of inhabiting the same territory destabilises claims generally made through the nation-state while highlighting the importance of the city as the scale at which new claims are now made. It further shows that it is possible to overcome 'differences' and that indeed, class, as opposed to nationality or ethnicity, is often mobilised to make progressive claims; claims that can eventually lead to more just cities.

At the same time, it is also important to recognise that these organisations are heavily stratified by gender. Women tend to participate in communitarian organisations that work for the wellbeing of those living in informal settlements, distancing themselves from the world of 
politics, even in cases where they do make political claims, including of a feminist nature. Some of these spaces, despite the fact that they are quite clearly an extension of women's caring roles, also provide new opportunities to challenge patriarchal constraints. As the examples above illustrate, actions that are not necessarily thought of as 'political' sometimes lead to the making of political claims, such as those for a gendered right to the city and the right for women to be free from violent relationships. Therefore, those organisations that organise on the basis of class and/or gender, albeit on assistentialist grounds, are able to make political claims. They have a vision for an alternative and more just city and therefore through their work make claims to their right to the city.

However, not all organisations lead to a more gendered right to the city. In fact, some of the examples included above also illustrate how some migrant organisations run the risk of becoming a parallel system of justice by providing migrant women with counsel in cases of domestic violence, tending to resolve these cases informally, instead of referring to existing support and justice systems. These actions undermine the development of a right to the city because they keep women and the problems they experience within culturally bound groups and networks that do not grant women equal rights. Within these contexts, women's claims are then subordinate to those made on the basis of nationality. Instead of understanding their situation and the problems that they might be experiencing as the outcome of intersections of gender, nation and class, the migrant organisations define a hierarchy in which nation and ethnicity are given priority over gender and class. They therefore undermine women's interests, as well as those that are shared among working class groups, across different nationalities and across people of differing migration status. Migrant organisations, which are based on nationality, are conservative in outlook, particularly in relation to gender and tend to relate to formal politics. While collaborating with city authorities, they do so from a culturally conservative basis, identifying migrants on the basis of their nationality only and women generally as submissive to men's interests. The evidence in relation to domestic violence is particularly worrying since it suggests that the presence of these migrant organisations precludes or at least discourages migrant women to seek support and justice through the available formal means.

\section{References}

Arendt, H. 1998. The human condition. Chicago: University of Chicago Press.

Balbo, M. 2007. International migrants and the city ed. UN-HABITAT: UN-HABITAT.

Barrios de Chungara, D.; M. Viezzer; and V. Ortiz. 1979. Let me speak! : testimony of Domitila, a woman of the Bolivian mines. London: Stage 1.

Basok, T.; N. Piper; and V. Simmons. 2013. Disciplining Female Migration in Argentina: Human Rights in the Time of Migration Management. In Disciplining the Transnational Mobility of People, ed. M. Geiger and A. Pecoud, 162-184. Basingstoke: Palgrave Mcmillan.

Bastia, T. and M. vom Hau. 2014. Migration, Race and Nationhood in Argentina. Journal of Ethnic and Migration Studies 40:475-492.

Brenner, N. and S. Elden. 2009. Henri Lefebvre on State, Space, Territory1. International Political Sociology 3:353-377. 
Buckley, M. and K. Strauss. 2016. With, against and beyond Lefebvre: Planetary urbanization and epistemic plurality. Environment and Planning D: Society and Space.

Castles, S. and M.J. Miller. 2009. The age of migration: international population movements in the modern world. New York ; London: Guilford Press.

Chant, S.H. and C. McIlwaine. 2016. Cities, slums and gender in the global south : towards a feminised urban future. New York: Routledge, Taylor \& Francis Group.

Comaroff, J. and J.L. Comaroff. 2012. Theory from the South: Or, how Euro-America is Evolving Toward Africa. Anthropological Forum 22:113-131.

Davis, M. 2007. Planet of slums. London ; New York: Verso.

Derickson, K.D. 2015. Urban geography I: Locating urban theory in the 'urban age'. Progress in Human Geography 39:647-657.

DeSena, J.N. 2008. Gender in an Urban World. Bingley: Emerald Publishing.

Grimson, A. 1999. Relatos de la diferencia y la igualdad: los bolivianos en Buenos Aires. Buenos Aires, Argentina: EUDEBA : Federación Latinoamericana de Facultades de Comunicación Social.

Harvey, D. 2008. The right to the city. New Left Review 53:18.

Hill Collins, P. 2009. Black feminist thought : knowledge, consciousness, and the politics of empowerment. New York: Routledge.

hooks, B. 1984. Feminist theory from margin to center. Boston, MA: South End Press.

INDEC. 2012. Censo Nacional de Población, Hogares y Viviendas 2010. Resultados Definitivos. Serie B, Nr 2, ed. I.N.d.E.y. Censos. Buenos Aires: Ministerio de Economía.

Jarvis, H.; P. Kantor; and J. Cloke. 2009. Cities and gender. London ; New York: Routledge.

Kipfer, S.; P. Saberi; and T. Wieditz. 2013. Henri Lefebvre. Progress in Human Geography 37:115-134.

Kofman, E. and E. Lebas. 1996. Lost in transposition: time, space and the city. In Writings on cities by Henri Lefebvre, ed. E. Kofman and E. Lebas, 3-64. Oxford: Blackwell.

Laurie, N. 1999. Geographies of new femininities. Harlow: Longman.

Lefebvre, H. 1996. The Right to the City. In Writings on Cities, ed. E. Kofman and E. Lebas. Oxford: Blackwell.

Lovenduski, J. 2005. Feminizing politics. Cambridge, UK ; Malden, MA: Polity Press.

Madden, D.J. 2012. City Becoming World: Nancy, Lefebvre, and the Global-Urban Imagination. Environment and Planning D: Society and Space 30:772-787.

Massey, D.B. 1994. Space, place, and gender. Minneapolis: University of Minnesota Press.

Mcllwaine, C. 2013. Urbanization and gender-based violence: exploring the paradoxes in the global South. Environment and Urbanization 25:65-79.

Miraftab, F. 2007. Governing Post Apartheid Spatiality: Implementing City Improvement Districts in Cape Town. Antipode 39:602-626.

Mitchell, D. 2003. The right to the city : social justice and the fight for public space. New York: Guilford Press.

Molyneux, M. 1985. Mobilization without Emancipation? Women's Interests, the State, and Revolution in Nicaragua. Feminist Studies 11:227-254.

Naples, N.A. 1991. "Just What Needed to Be Done": The Political Practice of Women Community Workers in Low-Income Neighborhoods. Gender and Society 5:478-494. 1992. ACTIVIST MOTHERING. Gender \& Society 6:441-463.

Patel, S. and D. Mitlin. 2002. Sharing experiences and changing lives. Community Development Journal 37:125-136.

Peake, L. 2015. The Twenty-First-Century Quest for Feminism and the Global Urban. International Journal of Urban and Regional Research:n/a-n/a. 
Peake, L. and M. Rieker. 2013. Rethinking feminist interventions into the urban. London ;: New York : Routledge, Taylor \& Francis Group.

Peck, J. and A. Tickell. 2002. Neoliberalizing Space. Antipode 34:380-404.

Perlman, J. 2010. Four Decades of Living on the Edge in Rio de Janeiro Oxford: Oxford University Press.

Purcell, M. 2003. Citizenship and the right to the global city: reimagining the capitalist world order. International Journal of Urban and Regional Research 27:564-590.

Robinson, J. 2006. Ordinary cities: between modernity and development. London ; New York: Routledge.

Roy, A. 2011. Slumdog Cities: Rethinking Subaltern Urbanism. International Journal of Urban and Regional Research 35:223-238.

Sassen, S. 1999. Cities: between global actors and local conditions: the 1997 Lefrak monograph. College Park, Md.: Urban Studies and Planning Program, University of Maryland.

Schindler, S. 2014. Understanding Urban Processes in Flint, Michigan: Approaching 'Subaltern Urbanism' Inductively. International Journal of Urban and Regional Research 38:791-804.

Simone, A.M. 2004. For the city yet to come : changing African life in four cities. Durham: Duke University Press.

2010. City life from Jakarta to Dakar : movements at the crossroads. New York: Routledge.

Swyngedouw, E. 2009. The Antinomies of the Postpolitical City: In Search of a Democratic Politics of Environmental Production. International Journal of Urban and Regional Research 33:601-620.

\footnotetext{
' 'Assistentialist' is here used to denote an organisation that aims to serve the social needs of a particular community, as opposed to one that has political aspirations. The word itself does not exist in the English dictionary but I retain its use as there is no current equivalent translation of the Spanish word 'asistencialista'.
} 